\title{
Pre-fermentative treatment of a model wine with aim to serve as a functional food with decreased alcohol content
}

\author{
Irina Mladenoska ${ }^{* 1}$, Verica Petkova ${ }^{1}$, Tatjana Kadifkova Panovska ${ }^{2}$ \\ ${ }^{I}$ Department of Food Technology and Biotechnology, Faculty of Technology and Metallurgy, \\ Ss. Cyril and Methodius University, Rudjer Boskovic, 16, 1000 Skopje, \\ Republic of Macedonia \\ ${ }^{2}$ Faculty of Pharmacy, Ss. Cyril and Methodius University, Majka Tereza 47, 1000 Skopje, \\ Republic of Macedonia
}

Received: November 2017; Accepted: December 2017

\begin{abstract}
The effect of substrate concentration on the enzyme activity in the reaction of glucose conversion into gluconic acid was investigated by using three different enzyme preparations in media with two different glucose concentrations. The media were simulating the conditions in the must, thus named as minimal model must, and were composed form combination of several organic acids and glucose. Those media were having initial $\mathrm{pH}$ of 3.5 that is a very unfavorable for glucose oxidase activity having a $\mathrm{pH}$ optimum at the $\mathrm{pH}$ value of 5.5. Among the three preparations used, the bakery additive, Alphamalt Gloxy 5080, was the most active in the medium with glucose concentration of $10 \mathrm{~g} / \mathrm{L}$, showing conversion of more than $70 \%$ for the period of $24 \mathrm{~h}$, while the same enzyme preparation in the medium with $100 \mathrm{~g} / \mathrm{L}$ glucose converted only about $7 \%$ of glucose. The $\mathrm{pH}$ value of the medium at the beginning and at the end of the enzymatic reaction was a good indicator of the enzyme activity. It seems that for the conversion of glucose in higher concentration, enzymatic preparation in high concentration should also be used. The preliminary attempt of immobilization of two preparations of glucose oxidases in alginate beads was also performed and a successful immobilization procedure for utilization in food industry was preliminarily developed.
\end{abstract}

Keywords: glucose oxidases, enzymatic pretreatment, glucose, gluconic acid, model wine, functional food

\section{Introduction}

During the last couple of decades, the interest among the nutritionists and food industry for production of low alcohol- and alcohol-free wines has been increased. It has been reported that the consumption of low alcohol wines had a very positive effect on the consumer's health. Thus, Karatzi et al. (2004) showed that the consumption of 250 $\mathrm{mL}$ per day of alcohol-free wine has improved the condition of the cardio-vascular system in patients with a progressive coronary disease. It was also reported that the consumption of alcohol-free wine has improved the condition of patients with a colorectal cancer (GlavasObrovac et al., 2006). There are, also, literature data witnessing the benefit of alcohol-free wine consumption and its connection with lowering the high blood pressure (Chiva-Blanch et al., 2012). It is also known that the Mediterranean nutrition style and moderate consumption of red wine in combination with olive oil-based diet, improved the consumer's health, the effect known as a French paradox (Yoo et al., 2010).

In order to produce low or alcohol-free wines, food industry applies several pre-, during and postfermentative procedures. Post-fermentative techniques are

*irinaetf@t.mk 
usually physical like pervaporation (Takacs et al., 2007) or utilization of spinning cone column (Belisario-Sanchez et al., 2012). But all of these processes have drawbacks such are specific and expensive equipment and changes in aromatic composition (Heux et al., 2006).

Unlike post-fermentative, pre-fermentative enzymatic methods for lowering the alcohol level in wines are faster, high specific methods that minimize loss or alteration of sensory qualities and off-flavor development (Schmidke et al., 2012). Oxidation of glucose, as one of the two fermentable sugars together with fructose, and production of gluconic acid with the enzyme glucose oxidase is one of the most promising enzymatic technique as pre-fermentative treatment of the must with the final aim- production of low alcohol wine (Biyela et al., 2009).

In the last decade, the application of the immobilized forms of glucose oxidase is in the focus of interest among the researchers working in this scientific area (GonzálezPombo et al., 2014; Romo-Sánchez et al., 2014).

In this paper the effect of glucose concentration in the minimal model must on the enzymatic activity of several different commercial glucose oxidase preparations was examined. The first one was the commercial bakery additive Alphamalt Gloxy 5080 (glucose oxidase and low catalase activity). The second one was pure glucose oxidase from the mould Aspergillus niger and the third preparation was coupled mold glucose oxidase and a beef liver catalase. The glucose concentration of $10 \mathrm{~g} / \mathrm{L}$ and $100 \mathrm{~g} / \mathrm{L}$ were used as sugar concentrations in the minimal model must. The effect of the enzyme activity on the final $\mathrm{pH}$ of the reaction media was also studied.

\section{Material and methods}

\section{Enzymatic preparations}

Alphamalt Gloxy 5080 (Muhlenchemie, Germany) was a commercial enzyme preparation obtained from Aspergillus niger strain. This was a food grade bakery additive with activity of 10500 units per gram (U/g) and low catalase activity. The pure glucose oxidase (GOX), (EC 1.1.3.4) was in its lyophilized form and was also derived from Aspergillus niger (Merck, Germany). This preparation was with much lower activity than the previous one. The activity of the lyophilized glucose oxidase was $8 \mathrm{U} / \mathrm{mg}$. The liquid catalase (CAT), (Merck, Germany) was obtained from beef liver and had an activity of $1300000 \mathrm{U} / \mathrm{mL}$.

\section{Media}

A medium with high glucose concentration of 100 $\mathrm{g} / \mathrm{L}$ was prepared. This high concentration was chosen to be of the same order of magnitude as the one measured in the real must. For comparison, the medium with lower concentration of glucose of $10 \mathrm{~g} / \mathrm{L}$ was also used. The minimal model must, besides glucose, was also containing
$4.0 \mathrm{~g} / \mathrm{L}$ tartaric acid, $1.5 \mathrm{~g} / \mathrm{L}$ malic acid and $0.5 \mathrm{~g} / \mathrm{L}$ citric acid. The $\mathrm{pH}$ of the medium was adjusted to $\mathrm{pH} 3.5$ using sodium hydroxide $(10 \mathrm{M} \mathrm{NaOH})$ to be similar as the $\mathrm{pH}$ of the real must.

\section{Glucose oxidase reaction}

All the three preparation used were diluted in the medium to give a certain concentration of the enzyme preparation. The reactions were carried on an orbital shaker (Ceromat R, B. Brown Biotech International) with agitation rate of $150 \mathrm{rpm}$ (oxygen dissolution) in $100 \mathrm{~mL}$ Erlenmeyer flasks containing $50 \mathrm{~mL}$ of medium. The reaction temperature was kept $30^{\circ} \mathrm{C}$.

\section{Determination of glucose concentration}

D-glucose was measured using DNS method for determination of reduced sugars (Miller, 1959). The absorbance was measured on a spectrophotometer Cary 50 Scan (Varian) at $540 \mathrm{~nm}$ wave length.

\section{Determination of $\mathrm{pH}$ value}

The $\mathrm{pH}$ value of the media was determined by utilization of Sartorius Basic pH Meter PB-11. The pH value was determined at the beginning (initial $\mathrm{pH}$ value) and at the end of the enzymatic reaction (final $\mathrm{pH}$ value).

\section{Immobilization procedure}

Enzymes glucose oxidase from Aspergillus niger (I) and glucose oxidase from Aspergillus niger coupled with catalase from bovine liver (II) were immobilized in alginate beads with entrapment. These beads were made by mixing two solutions: anionic solution (4\% w/v Naalginate) and cationic solution $\left(5.5 \% \mathrm{w} / \mathrm{v} \mathrm{CaCl}_{2} \cdot 2 \mathrm{H}_{2} \mathrm{O}\right)$. The enzymes were, firstly, dissolved in the anionic solution and then poured in the cationic solution, drop by drop. During the gelation process, the beads were formed. The diameter of the beads formed was $4.5 \pm 0.5$ $\mathrm{mm}$.

\section{Results and discussion}

Enzymatic reaction in the minimal model must with $10 \mathrm{~g} / \mathrm{L}$ glucose

The mechanism of the enzymatic oxidation of the $\beta$-D-glucose to a gluconic acid is presented at the Fig. 1.

The effect of the lower concentration of glucose, 10 $\mathrm{g} / \mathrm{L}$, on the enzymatic activity was evaluated by utilizing three different glucose oxidase preparations in the medium simulating a must (minimal model must). Those were Alphamalt Gloxy 5080, pure glucose oxidase and the third one was a combination of glucose oxidase and catalase (Fig. 2). As can be seen from the Fig. 1, the most active of all the three was the commercial Alphamalt 


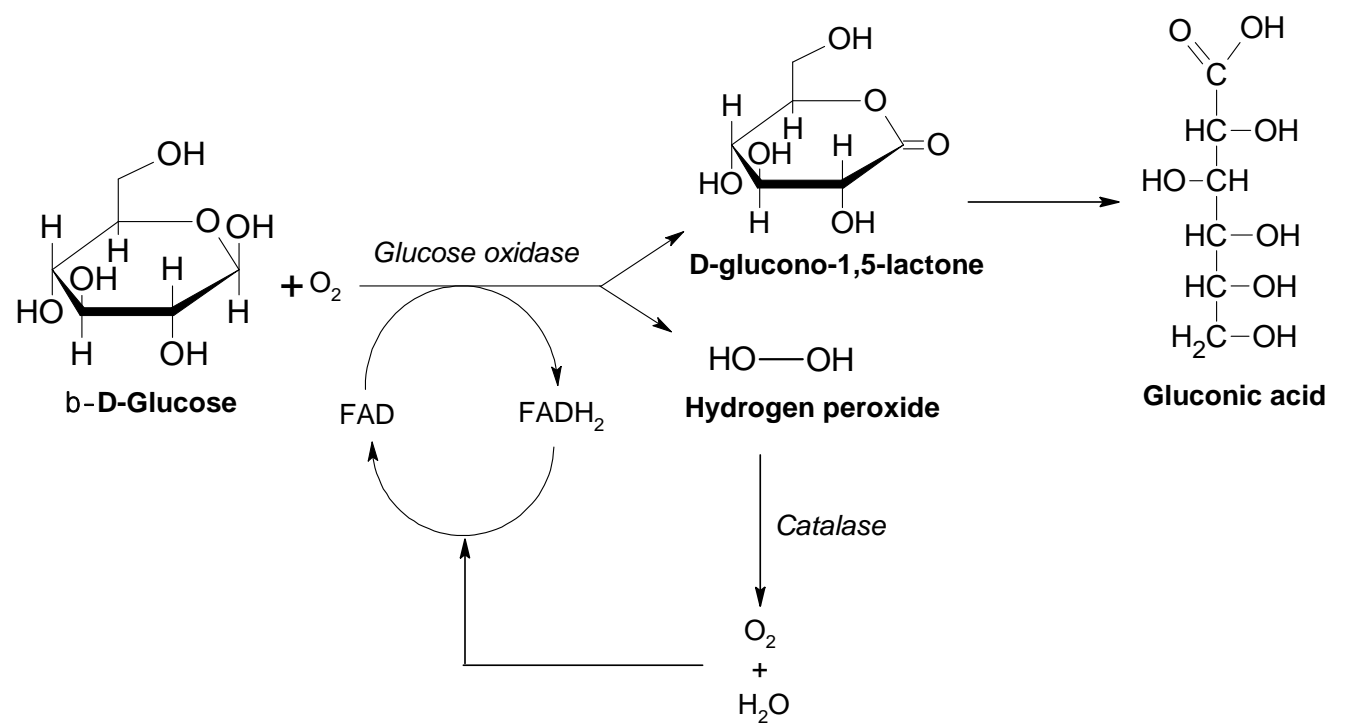

Fig. 1 The conversion of glucose into a gluconic acid by glucose oxidase proceeds via a two step reaction.

Gloxy 5080 preparation, showing even $71.12 \%$ conversion at the $24^{\text {th }}$ hour of the reaction. Unlike the Alphamalt Gloxy 5080, the other two glucose oxidase preparations showed negligible activity towards the glucose substrate used in the concentration of $10 \mathrm{~g} / \mathrm{L}$. It is, thus, obvious, that not even the presence of catalase, could not increase the activity of the pure glucose oxidase, in this, not favorable conditions for the enzyme activity (pH 3.5).

Enzymatic reaction in the minimal model must with 100 $g / L$

In the second experiment, ten times higher concentration of glucose was used, as it was actually necessary to simulate the concentration of glucose present in the real must (approx. $100 \mathrm{~g} / \mathrm{L}$ glucose $+100 \mathrm{~g} / \mathrm{L}$ fructose). As can be seen from the results presented at the Fig. 3, none of the three enzymatic preparations used was active enough at this high concentration of glucose. However, the Alphamalt Gloxy 508 showed certain activity. Namely, during the reaction period of 120 hours it converted only $7.37 \%$ of the substrate. It can be assumed that for the conversion of glucose into gluconic acid in media with high glucose concentration, at these unfavorable conditions for glucose oxidase activity, the acidic environment, high concentrations of enzyme preparation, preferably Alphamalt Gloxy 508, should be used.

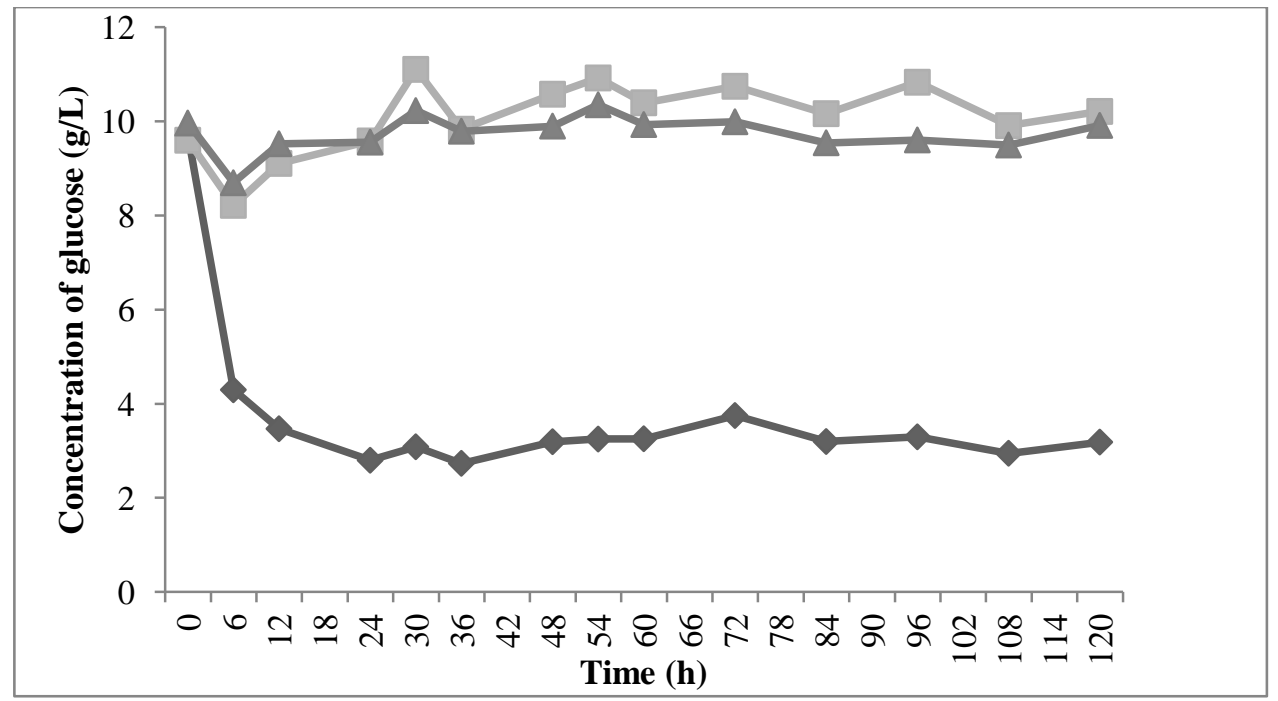

Fig. 2 Time course of the glucose oxidation by the three different glucose oxidase preparations: Alphamalt Gloxy $5080(\downarrow)$, glucose oxidase ( $\bullet$ ) and glucose oxidase + catalase $(\mathbf{A})$ in the medium containing $10 \mathrm{~g} / \mathrm{L}$ glucose.

Макед. фарм. билт., 63 (1) 47 - 53 (2017) 


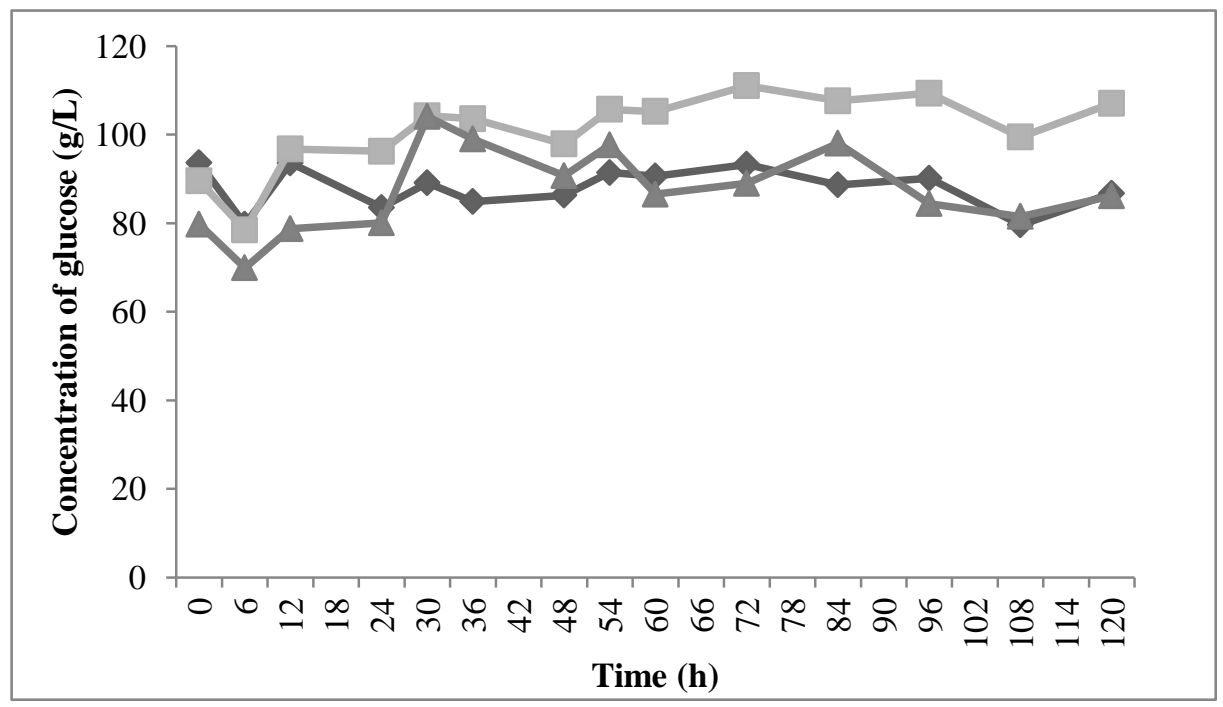

Fig. 3 Time course of the glucose oxidation by the three different glucose oxidase preparations: Alphamalt Gloxy 5080 $(\diamond)$, glucose oxidase $(\boldsymbol{\square})$ and glucose oxidase + catalase $(\boldsymbol{\Delta})$ in the medium containing $100 \mathrm{~g} / \mathrm{L}$ glucose.

The $\mathrm{pH}$ value of the media and its difference between the initial and the final value (after the reaction), is also a good indirect indicator of the enzymatic activity. Thus, the very logical results were obtained when the $\mathrm{pH}$ value of the medium containing $100 \mathrm{~g} / \mathrm{L}$ was used as a minimal model must (Table 1). Only a very slight difference in the $\mathrm{pH}$ value (from 3.55 to 3.50) was measured in the medium with coupled glucose oxidase/ catalase enzymatic system used as catalyst. It is interesting that the Alphamalt Gloxy 5080 has changed the $\mathrm{pH}$ value of the medium from 3.50 to $\mathrm{pH} 3.00$, and it was the most active enzymatic preparation among the three examined.

\section{Immobilization of the enzymes}

In this work a very successful immobilization technique of two different glucose oxidase preparations, an entrapment in alginate beads, was developed. The entrapped enzymatic preparations, (I) glucose oxidase from Aspergillus niger and (II) glucose oxidase from Aspergillus niger coupled with catalase from bovine liver, were used as catalysts for glucose conversion into a gluconic acid. The appearance of the alginate beads is presented on the Fig. 4 .

It is interesting that the alginate beads, commonly very compatible for utilization in food processes, appeared to be suitable carriers for application of enzymes even in very acidic conditions, such as the synthetic grape juice has. The time course of the glucose oxidation, catalyzed with 4 different enzymatic systems (1. crude glucose oxidase, 2. crude glucose oxidase coupled with catalase, 3 . entrapped glucose oxidase and 4. glucose oxidase coimmobilized with liver catalase), is presented at the Fig. 5.

Table 1. The pH value of the minimal model must at the beginning and at the end of the enzymatic glucose conversion Change of $\mathrm{pH}$ value in MMM with $100 \mathrm{~g} / \mathrm{L}$ glucose

\begin{tabular}{|c|c|c|c|c|}
\hline & control & $\begin{array}{c}2 \mathrm{~g} / \mathrm{L} \\
\text { Alphamalt }\end{array}$ & $25 \mathrm{mg} / \mathrm{L} \mathrm{GOX}$ & $\begin{array}{c}25 \mathrm{mg} / \mathrm{L} \mathrm{GOX}+25 \mu \mathrm{L} \\
\mathrm{CAT}\end{array}$ \\
\hline starting $\mathrm{pH}$ value & 3.55 & 3.55 & 3.55 & 3.55 \\
\hline final $\mathrm{pH}$ value & 3.55 & 3.00 & 3.53 & 3.50 \\
\hline
\end{tabular}




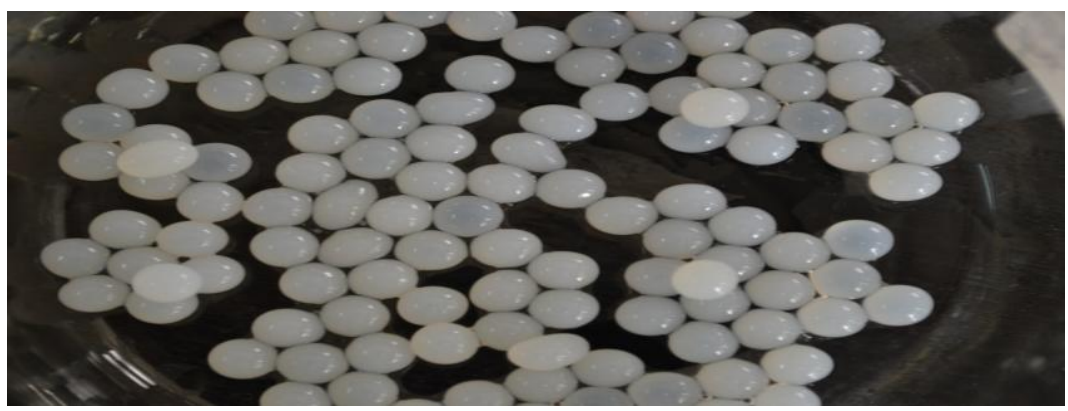

Fig. 4 Appearance of the alginate beads with entrapped enzymes.

As it was expected, the highest conversion yield of $46.90 \%$ was measured at the $48^{\text {th }}$ hour of the reaction in the system having coupled crude glucose oxidase and catalase, as enzymatic preparations. After this reaction time, the reaction reached a plateau. The sole crude glucose oxidase has converted much less glucose, showing the conversion yield of $25.57 \%$ at the $48^{\text {th }}$ hour of the catalytic reaction. The immobilized enzyme preparations showed much lower conversion yields than the crude preparations, which is understandable and is a result of the internal diffusion limitations. Thus, the conversion yield at the $48^{\text {th }}$ hour of only $5.51 \%$ was reached when only the glucose oxidase entrapped in alginate beads was used, while the yield of $23.72 \%$ was reached when coupled glucose oxidase and catalase were used as a coimmobilized enzyme preparation.

This means that the activity of the immobilized coupled enzymatic preparations (glucose oxidase + catalase) was approximately half of the activity of the free coupled preparations.

\section{Conclusion}

The effect of glucose concentration on enzyme activity was evaluated by utilization of three different enzymatic preparations. It was found out that the commercial bakery additive Alphamalt Gloxy 5080 was the most suitable enzymatic preparation for glucose oxidation at as low $\mathrm{pH}$ of the medium as $\mathrm{pH} 3.5$, although even this enzymatic preparation has not very active at the higher glucose concentration $(100 \mathrm{~g} / \mathrm{L})$. The immobilization process - entrapment of the enzymes in alginate beads, has also been shown as a successful process and a possibility for application of those enzymes in the food industry. This paper is only a part of the complex research process for development of a sophisticated method for pre-fermentative lowering of the sugar concentration in the must, with final aim production of low alcohol wine.

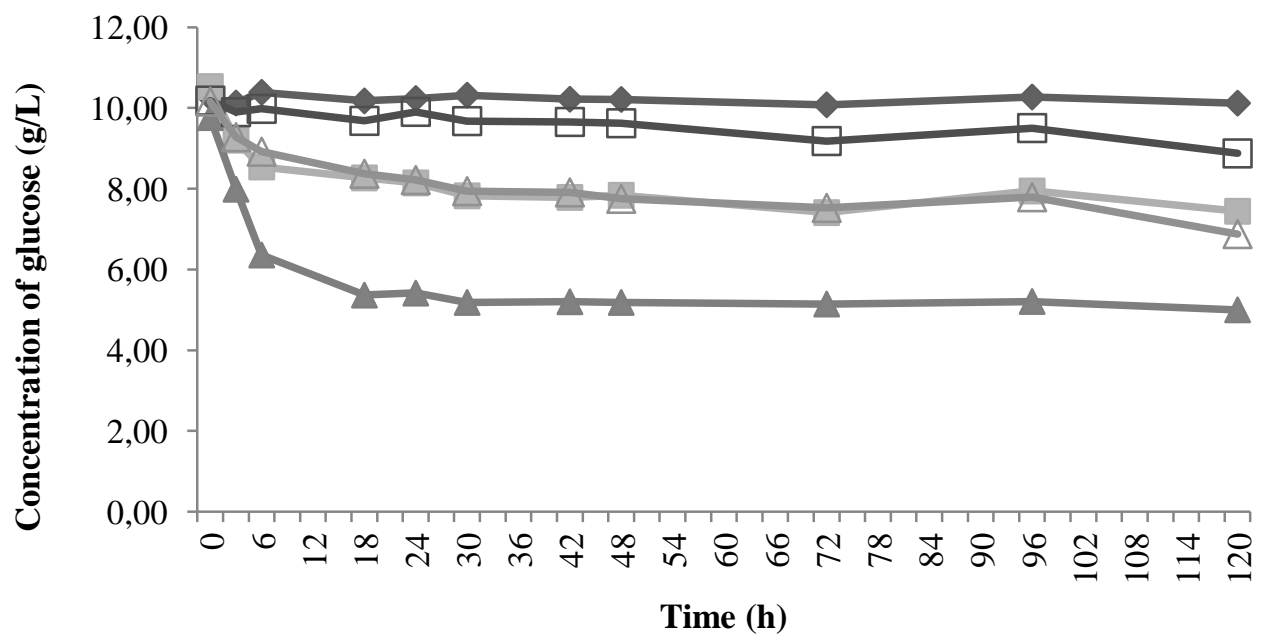

Fig. 5 Time course of glucose oxidation in minimal model must catalyzed with four different enzymatic systems control $(\downarrow)$, crude glucose oxidase $(\boldsymbol{\bullet})$, crude glucose oxidase and catalase $(\boldsymbol{\Delta})$, immobilized glucose oxidase $(\square)$ and coimmobilized glucose oxidase and catalase $(\Delta)$. 


\section{References}

Belisario-Sanchez, Y.Y., Taboada-Rodriguez, A., MarinIniesta, F., Iguaz-Gainza, A., Lopez-Gomez, A., 2012. Aroma recovery in wine dealcoholization by SCC distillation. Food Bioproc. Technol. 5, 2529-2539. Available at: https://doi.org/10.1007/s11947-011-0574-y.

Biyela, B.N.E., du Toit, W.J., Divol, B., Malherhe, D.F., van Renshurg, P., 2009. The production of reduced-alcohol wines using Gluzyme Monor 10000 BG-treated grape juice. S. Afr. J. Enol. Vitic. 30, 124-132.

Chiva-Blanch, G., Urpi-Sarda, M., Ros, E., Arrans, S., Valderas-Martinez, P., Casas, R., Sacanella, E., Liorach, R., Lamuela-Raventos, R.M., Andres-Lacueva, C., Estruch, R., 2012. Dealcoholized red wine decreases systolic and diastolic blood pressure and increases plazma nitric oxide: short communication. Circ. Res. 111, 10651072. Available at: https://doi.org/10.1161/CIRCRESAHA.112.275636.

Glavaš-Obrovac, L.J., Opačak, T., Bareš, V., Šubarić, D., Babić, J., Ilakovac, V., Karner, I., 2006. Effects of dealcoholized red and white wines on human tumor and normal cells proliferation. Acta Alimen. 35, 153-162. Available at: https://doi.org/10.1556/AAlim.35.2006.2.2.

González-Pombo, P., Fariña, L., Carrau, F., Batista-Viera, F., Brena, B.M., 2014. Aroma enhancement in wines using co-immobilized Aspergillus niger glycosidases. Food Chem. 143, 185-191. Available at: https://doi.org/10.1016/j.foodchem.2013.07.107.

Heux, S., Sablayrolles, J.M., Cachon, R., Dequin, S., 2006. Engineering a Saccharomyces cerevisiae wine yeast that exhibits reduced ethanol production during fermentation under controlled microoxygenation conditions. Appl. Environ. Microbiol. 72, 5822-5829. Available at: https://doi.org/10.1128/AEM.00750-06.

Karatzi, K., Papamichael, C., Aznouridis, K., Karatzis, E., Lekakis, J., Matsouka, C., Boskou, G., Chiou, A., Sitara, M. Feliou, G., Kontoyiannis, D., Zampelas, A., Mavrikakis, M., 2004. Constituents of red wine other than alcohol improve endothelial function in patients with coronary artery disease. Coron. Artery Dis. 15, 485-490. Available at: https://doi.org/10.1097/00019501-200412000-00005.

Miller, G.L. 1959. Use of dinitrosalicylic acid reagent for determination of reducing sugar. Anal. Chem. 31, 426-428. Available at: https://doi.org/10.1021/ac60147a030.

Romo-Sánchez, S., Arévalo-Villena, M., Romero, E.G., Ramirez, H.L., Pérez, A.B., 2014. Immobilization of $\beta$ glucosidase and its application for enhancement of aroma precursors in muscat wine. Food bioproc. Technol. 7(5), 1381-1392. Available at: https://doi.org/10.1007/s11947-013-1161-1.

Schmidke, L.M., Blackman J.W., Agboola, S.O., 2012. Production technologies for reduced alcoholic wines. J. Food Sci. 77, 25-41. Available at: https://doi.org/10.1111/j.17503841.2011.02448.x.

Takacs, L., Vatai, G., Korany, K., 2007. Production of alcoholfree wine by pervaporation. J. Food Eng. 78, 118-125. Available at: https://doi.org/10.1016/j.jfoodeng.2005.09.005.

Yoo, Y.J., Saliba, A.J., Prenzler, P.D., 2010. Should red wine be considered a functional food? Compr. Rev. Food Sci. Food Saf. 9, 530-551. Available at: https://doi.org/10.1111/j.1541-4337.2010.00125.x. 


\title{
Резиме
}

\section{Преферментативно третирање на моделен раствор на вино се цел добивање функционална храна со намалено количество}

\author{
Ирина Младеноска ${ }^{1}$, Верица Петкова ${ }^{1}$, Татјана Кадифкова Пановска ${ }^{2}$ \\ ${ }^{1}$ Оддел за прехранбена технологија и биотехнологија, \\ Технолошко-металуршки факултет, Универзитет „Св. Кирил и Методиј”, \\ Руѓер Бошковиќ 16, 1000 Скопје, Република Македонија \\ ${ }^{2}$ Фармацевтски факултет, Универзитет „Св. Кирил и Методиј”, Мајка Тереза 47, \\ 1000 Скопје, Република Македонија
}

Клучни зборови: глукооксидази, ензимски предтретман, глукоза, глуконска киселина, модел на вино, функционална храна

Влијанието на супстратната концентрација врз ензимската активност во реакција на конверзија на глукоза во глуконска киселина беше испитувана со користење на три различни ензимски препарати во медиуми со две различни концентрации на глукоза. Медиумите симулираа услови (состав) на шира, па беа наречени минимални модели на шира и беа составени од комбинација на неколку органски киселини и глукоза. Овие медиуми имаа почетно $\mathrm{pH} 3,5$; вредност што е несоодветна за активноста на глукооксидазата што има најголена активност при оптимална $\mathrm{pH}$ вредност од 5,5. Помеѓу трите препарата користени, адитивот за пекарство, Alphamalt Gloxy 5080, е најактивниот во медим со концентрација на глукоза од $10 \mathrm{~g} / \mathrm{L}$ и покажува конверзија од повеќе од $70 \%$ за период од 24 часа, додека истиот ензимски препарат во медиум со $100 \mathrm{~g} / \mathrm{L}$ глукоза ковертира околу 7\% супстрат. Почетната и крајната вредност на $\mathrm{pH}$ на медиумот, односно вредностите мерени на почеток и крај на ензимската реакција, се добри показатели за ензимската активност. Изгледа дека за конверзија на глукоза во вискоки концентрации треба да се користат активни ензими во повисоки концентрации. Прелиминарни обиди за имобилизација на два препарата на глукооксидаза во алгинатни капсули, се истотака направени. Се чини дека успешен метод за имобилизација применлив во прехранбената индустија е креиран. 
